DIGITAL COMMONS
@ UNIVERSITY OF SOUTH FLORIDA

Volume 11

Issue 1 Summer 2021

\section{ABO: Interactive Journal for Women in the Arts, 1640-1830}

\title{
Review of The Future of Feminist Eighteenth-Century Scholarship: Beyond Recovery, edited by Robin Runia
}

\author{
Erin M. Goss \\ Clemson University, erinm.goss@gmail.com
}

Follow this and additional works at: https://digitalcommons.usf.edu/abo

Part of the Dramatic Literature, Criticism and Theory Commons, Educational Methods Commons, Feminist, Gender, and Sexuality Studies Commons, and the Literature in English, British Isles Commons

\section{Recommended Citation}

Goss, Erin M. (2021) "Review of The Future of Feminist Eighteenth-Century Scholarship: Beyond Recovery, edited by Robin Runia," ABO: Interactive Journal for Women in the Arts, 1640-1830: Vol.11: Iss.1, Article 18.

http://doi.org/10.5038/2157-7129.11.1.1244

Available at: https://digitalcommons.usf.edu/abo/vol11/iss1/18

This Reviews is brought to you for free and open access by Digital Commons @ University of South Florida. It has been accepted for inclusion in ABO: Interactive Journal for Women in the Arts, 1640-1830 by an authorized administrator of Digital Commons @ University of South Florida. For more information, please contact digitalcommons@usf.edu. 


\title{
Review of The Future of Feminist Eighteenth-Century Scholarship: Beyond Recovery, edited by Robin Runia
}

\author{
Abstract \\ Review of Robin Rubia, ed., The Future of Feminist Eighteenth-Century Scholarship: Beyond Recovery \\ (Routledge, 2018) \\ Creative Commons License \\ (c) (1) (9)
}

This work is licensed under a Creative Commons Attribution-Noncommercial 4.0 License 
Robin Runia, ed. The Future of Feminist Eighteenth-Century Scholarship: Beyond Recovery. Routledge Studies in Eighteenth-Century Literature, 2018. 200 pp. ISBN: 9781138571372

Reviewed by Erin M. Goss

Clemson University

What is the future of feminist scholarship in eighteenth-century studies if feminist criticism itself is a dated project? Robin Runia's collection begins by asking this question and acknowledging an "uncomfortable undercurrent" that wonders if what feminism had to do in literary study has already been done. Framed partially in terms of the extent to which various recovery projects of the past several decades have unearthed the voices of those women long neglected, such a question invites both a potential answer in the affirmative and also, of course, an insistently impossible negative. That is, while it is salutary to reflect upon the vast number of women writers who have been rediscovered, we must surely imagine that not all voices have been disinterred and brought back to the attention of a present. What would it mean, after all, to have found a way to hear everyone? In asking after the future of feminist eighteenth-century scholarship, Runia's collection invites readers to consider (again) arguments that have long been made for the recovery of women's writing. Her introduction, though, also acknowledges the potential datedness of an approach that assumes sex to be the most salient form of available difference. Rather than returning to debates about essentialism or even modes of reading, Runia introduces her collection with a reflection on the status not of feminist criticism but of the feminist critic, whose institutional and scholarly life has become itself a kind of project for contemporary feminism. Such a reflection is welcome and intriguing and could have made for an even more compelling collection had it been taken up in the essays that followed. How does this work of recovery and feminist reading affect the recoverers? And if we are to reflect on the institutional commitment of feminist scholarship, how might we consider more vigorously the relationship of the dual feminist projects of scholarly recovery and pedagogy, or what Charlie Yi Zhang calls teaching as "slow activism"?

Runia's invitation to imagine the future of feminist recovery scholarship becomes a call for feminist introspection. In recognizing the complicity of an institutionally recognized feminist scholarship in the forms of injustice and prejudicial practices inherent in institutional life, Runia suggests both a future and a conclusion to the 
feminist critical endeavor as it has been practiced. On the one hand, in order to have a future, feminist critics must "interrogate our own positionality regarding gender, race, and class and see where we benefit from these systems as well as suffer from them" (5). On the other hand, feminist criticism has had some time to do that work, and it is not abundantly clear that it has done it. There is something apologetic about Runia's introduction, and well there might be, given the sometimes nascent and often overt racism and classism to be found in the history of feminist scholarship. As a reader, I was prepared to engage with some of what Runia calls the "mistakes" of earlier feminist readings as I turned to the essays and was, admittedly, a bit disappointed not to find that a more discernible thread in the collection. I say this even as I acknowledge and accept the impossible position into which a collection based on recognizing past critical mistakes would place its editor.

Rather than a catalogue of mistakes, what one finds in Runia's collection is a lively and ranging compendium of arguments demonstrating the energy that reading women's writing can generate. If the book's fundamental question is whether feminist criticism should keep at it, then the essays in the collection offer an affirmative answer. Most essays in the collection take up women writers already well represented in scholarship on the period, which suggests the "beyond recovery" of the book's subtitle to be a sign that it is time to get down to the work of reading the things that have been unearthed from historical forgetting.

Part I is loosely held together under the umbrella term "Concepts" and offers a pair of essays on new ways to think about old things. Cynthia Richards asks readers to think about how traumas implicit in various genres can be made accessible to students, and how the classroom can become a space of reckoning for students in the present. Richards makes a compelling call for the value and usefulness of what too quickly gets written off as "presentism," reminding us that our students live and struggle in the present and that the texts we share with them may provide ways to help them continue to do both of those things. In this same section and with a similar eye toward present concerns, Shaun Lisa Maurer applies the lens of "adolescence" she adopted to read Sense and Sensibility (Eighteenth-Century Fiction 25.4, 2013) to Pride and Prejudice's Lydia Bennet, to similarly useful effect. Like the earlier essay, I imagine that this addition will be a favorite with my students. 
Part II, "Intellects and Aesthetics," extends the idea of what feminist criticism beyond recovery might look like as it pairs a lesser-known writer with one of the more standard members of the canon of women writers. Karen Bloom Gevirtz's essay on Jane Barker invites attention to a writer who rarely appears in anthologies and convincingly demonstrates her integration of poetry and philosophy in ways that leave a reader wondering why she has been so absent from critical conversations. While Gevirtz leaves a reader wanting to know more about Barker, Brittany Pladek's essay on Letitia Landon shows a reader that they have come to know the wrong things about poets that Letitia Landon can help them rethink. Turning to the fairly standard figure of the poet-healer as visible in the poetry of Wordsworth and Keats, Pladek shows that Landon provides a model of the reader as healer in ways that provide suggestive links back to the collection's first essay on trauma and pedagogy.

Part III, rather abstractly and perhaps not totally helpfully called "Politics," offers two excellent essays on relatively well-discussed texts from two very different contexts. Stacey L. Kikendall reads the travel narratives of Mary Wollstonecraft and Mary Shelley, showing the ways that for both authors the travel writing genre becomes a site of tension between the radicalism of the nascent feminist proclivities that allow them to travel and the conservative prudence with which they report their experiences. Emily MN Kugler's essay on The History of Mary Prince grapples with a similar tension between experience and audience, though the stakes are much higher in her reflections on the white abolitionist women who shaped Mary Prince's narrative of Black life as both editors of and spectatorial audience to her story.

The collection's final section, called "Texts," offers the very broadest of headings but in some ways the most precise of interventions. Indeed, I found Kate Parker's excellent essay on women translators to be the most compelling of the collection in its work not only to uncover new writers but also to reflect attentively on what a focus on translation offers to recovery and scholarship on women writers as it has proceeded thus far. Both providing new content in its extensive discussion of a version of women's writing that has received very little critical attention and using that discussion to reflect on the idea of recovery as it has functioned in feminist scholarship of the period, Parker's essay most fully embraces the apparent task of the collection to imagine a future feminist scholarship that differs from that of the past. Attending to the ways that biographical insistences of recovery have led critics to "privilege[] a form of authorial self-possession that is 
radically undone by the act of translation" (133), Parker demonstrates the ways that focus on translation and on women translators provides a means to discuss authorship and writing outside of insistences on what she calls "autonomous selfactualization." Parker suggests that the future of feminist scholarship may indeed lie in overturning or leaving behind "one of the most powerful assumptions framing our narratives of recovery," as attention to translation allows for a more capacious notion of writing and authorship than the insistence that "originality and creativity are the only true means for disrupting the historically patriarchal realm of literary aesthetics" (135). The readings Parker provides bear out her discussion and provide models for ways to think beyond such assumptions. As the field pushes itself (one hopes) to become more capaciously transnational and increasingly less invested in notions of canon, Parker's work with translation can provide ways to think about other forms of writing that are mutually and collaboratively produced.

In the same section called "Texts" appear Jennifer L. Airey's essay on Maria Elizabeth Robinson, the daughter of the much more widely considered Mary Robinson, and Robin Runia's own essay on Maria Edgeworth's correspondence. In turning attention to texts that have received scant attention, Airey and Runia both demonstrate ways that the recovery project has not yet, as Runia asks in her introduction, arrived at a point when it can be said to be complete. Airey successfully introduces a writer and novel of which few are likely to know much, and I would have loved to see some of the insights from Parker's essay applied to the consideration of both. Indeed, Robinson's novel seems to invite discussion of a publicly collaborative authorship - perhaps like that thematized in Elizabeth Nieman's recent work on the Minerva Press - more than claims to "literary talent" and the kinds of assumptions that Parker suggests we might move beyond. Runia, by contrast, turns to Edgeworth's letters to discuss the ways that the methods with which feminist scholars are accustomed to approach such material have been hampered and limited by both the ideological assumptions Parker discusses and the material questions attendant on the study of prolific letterwriters. Recognizing the importance of digital methods to the future of feminist scholarship, Runia's insistence that "we must go back to the archive even as the archive comes to us" is a point well taken (165). Because the critical stories we have told about women authors in the past have produced the archive from which we have told our stories, Runia suggests, it is time for a renewed attention to archives that can change the questions we bring to them. 


\begin{abstract}
All told, this collection offers a valuable contribution to scholarship on women writers of the period. While many of the chapters could appear in any collection on such a topic, I was most compelled by those that took up Runia's challenge in the introduction to think about how a future of feminist scholarship might differ from that of the past. What can feminist scholarship be other than what it has been? There are many questions that remain unanswered and perhaps some that remain unasked, chief among them how the future of feminist eighteenth-century scholarship might begin to trouble and work through the insistent whiteness of its past. There is some hope to be found here, but as is ever the case there is still much to be done, making the titular insistence on the Future of Feminist Eighteenth-Century Scholarship all the more appropriate.
\end{abstract}

